in vivo $32: 1045-1050(2018)$

doi:10.21873/invivo.11345

\title{
Association of Matrix Metalloproteinase-7 Genotypes with the Risk of Bladder Cancer
}

\author{
CHENG-HSI LIAO ${ }^{1,2,3 *}$, WEN-SHIN CHANG ${ }^{4 *}$, CHIA-WEN TSAI ${ }^{4 *}$, PEI-SHIN HU ${ }^{5}$, \\ HSI-CHIN WU ${ }^{4}$, SHIH-WEI HSU ${ }^{1,2,3}$, GUAN-LIANG CHEN ${ }^{1,3}$, TE-CHENG YUEH ${ }^{1,2,3}$, \\ TE-CHUN SHEN ${ }^{4}$, TE-CHUN HSIA ${ }^{4}$ and DA-TIAN BAU ${ }^{1,4,6}$ \\ ${ }^{I}$ Graduate Institute of Biomedical Sciences, China Medical University, Taichung, Taiwan, R.O.C.; \\ ${ }^{2}$ Department of Surgery, Taichung Armed Forces General Hospital, Taichung, Taiwan, R.O.C.; \\ ${ }^{3}$ National Defense Medical Center, Taipei, Taiwan, R.O.C.; \\ ${ }^{4}$ Terry Fox Cancer Research Laboratory, Translational Medicine Research Center, \\ China Medical University Hospital, Taichung, Taiwan, R.O.C.; \\ ${ }^{5}$ Department of Ophthalmology, Changhua Christian Hospital, Changhua, Taiwan, R.O.C.; \\ ${ }^{6}$ Department of Bioinformatics and Medical Engineering, Asia University, Taichung, Taiwan, R.O.C.
}

\begin{abstract}
Background/Aim: The breakage of matrix metalloproteinases (MMPs) has been reported to be one of the mechanisms required for tumor invasion, and the expression of MMP-7 in serum is correlated with poor prognosis of urinary bladder cancer patients. However, the role of the MMP-7 genotypes has been seldom examined among bladder cancer patients. Therefore, this study aimed at examining the promoter polymorphic MMP-7 genotypes A-181G and C-153T among Taiwanese bladder cancer patients and evaluate the contribution of the genotypic variants of MMP-7 to bladder cancer risk in Taiwan. Materials and Methods: Three hundred and seventy-five bladder cancer patients and the same number of gender-and age-matched healthy controls were genotyped for A-181G and $C-153 T$ in the promoter of MMP-7 via polymerase chain reaction-restriction fragment length polymorphism methodology. Results: The frequencies of $A A, A G$ and $G G$ at $A-181 G$ of the promoter of MMP-7 were 89.1, 8.8 and $2.1 \%$ in the bladder cancer patient group and 87.5, 10.9 and $1.6 \%$ in the matched healthy control group, respectively ( $p$ for
\end{abstract}

This article is freely accessible online.

*These Authors contributed equally to this study.

Correspondence to: Da-Tian Bau, Terry Fox Cancer Research Laboratory, Translational Medicine Research Center, China Medical University Hospital, 2 Yuh-Der Road, Taichung, 404 Taiwan, R.O.C Tel: +886422053366 (Ext. 5805), e-mail: datian@mail.cmuh.org.tw; artbau2@gmail.com

Key Words: Bladder cancer, genotype, MMP-7, polymorphism, Taiwan. trend=0.5475). There was no polymorphic genotype for MMP-7 C-153T among the Taiwanese population. The comparisons in allelic frequency distribution also support the findings that the $G$ allele may not be the determinant allele for bladder cancer in Taiwan. In addition, the results showed that there is no significant association of the bladder risk with the MMP-7 A-181G genotype, even after adjustment for the possible confounding factors. Furthermore, there is no interaction of the genotypes of MMP-7 with age, gender, smoking and alcohol consumption on bladder cancer risk. Conclusion: The results of this study suggest that the two MMP-7 polymorphisms, - A-181G and $C-153 T$, do not play a major role in determining personal susceptibility to bladder cancer in Taiwan.

Bladder cancer is the 2nd most common urological malignancy worldwide, contributing to about $5 \%$ of cancer deaths and is estimated to cost four million dollars each year (1). According to the statistical data provided by the International Agency for Research on Cancer, there were an estimated 429,800 new cases of bladder cancer and 165,100 deaths in 2012 worldwide, and males are four times more likely to develop the disease than females $(1,2)$. In Taiwan, bladder cancer ranks seventh in incidence and mortality among the common types of cancer $(3,4)$. Tumorigenesis of bladder cancer is a complex, multistep and multifactorial process being the result of interactions of lifestyle, environmental and genetic factors (3-9).

The matrix metalloproteinases (MMPs, matrixins) are a family of endopeptidases that have been reported to play a key role in maintaining the homeostasis of extracellular matrix (ECM) components and the processes of inflammation, carcinogenesis and cancer cell migration $(10,11)$. Since the 
early 1990's, several kinds of MMPs were found to be overexpressed in tumor and stromal cells in the tissues from various types of cancer, and this was highly associated with invasion and progression of tumorigenesis $(12,13)$. In addition, MMPs released from distant organs, together with growth factors, can play a role in the initiation of metastasis $(14,15)$. In our body, MMP-7 has been shown to be constitutively produced by the mammary and parotid glands, pancreas, liver, prostate and lung peribronchial glands (16). In the past years, accumulating evidence indicated that the functional polymorphisms of MMPs may contribute to inter-individual differences in susceptibility to several types of cancer (17-26). Furthermore, the basal promoter activity was higher in promoter constructs harboring the combination of the two rare alleles of MMP-7 at A-181G (rs11568818) and C-153T (rs11568819) (27). These two promoter polymorphisms were reported to be associated with the coronary artery dimensions (27). In cancer genomic association studies, the genotypes of $M M P-7$ were investigated for their association with many types of cancer, including lung, breast, esophageal, gastric, colorectal, gallbladder, oral, cervical cancer, astrocytoma, childhood leukemia and renal cell carcinoma (28-40), but seldom in bladder cancer (41).

It is reported that high tissue and serum levels of MMP-7 are significantly and independently associated with poor prognosis among bladder cancer patients (42). However, there is only one study that examined the contribution of MMP-7 genotypes to bladder cancer risk (41). The study that included 241 bladder cancer cases and 199 healthy controls from two hospitals in Poland demonstrated that the genotypes of either MMP-7 (rs 11568818) or MMP-8 (rs11225395) were not differentially distributed between the two groups (41).

In light of all the above, the purpose of the current study was to investigate the association of MMP-7 genotypes at the promoter region, A-181G (rs11568818) and C-153T (rs11568819), to the risk of bladder cancer in a larger and more representative (case:control=375:375) Taiwanese population.

\section{Materials and Methods}

Investigated population. The current study was approved by the Institutional Review Board of the China Medical University Hospital (DMR104-IRB-158) and written-informed consent has been obtained from all the participants. All the clinical investigations were conducted according to the principles expressed in the Declaration of Helsinki. Totally, three hundred and seventyfive patients diagnosed with bladder cancer were recruited at the China Medical University Hospital in central Taiwan. All the recruited patients voluntarily participated, completed a selfadministered questionnaire and provided $5 \mathrm{ml}$ of their peripheral blood. The clinical characteristics of patients including histological details were all graded and defined by expert surgeons. An equal number of non-cancer healthy controls were selected by matching for age and gender after initial random sampling from the Health Examination Cohort of the hospital. The exclusion criteria of the control group included previous malignancy, metastasized cancer from other or unknown origin, and any familial or genetic diseases. Both groups completed a short questionnaire which included personal habits. Smokers were defined as daily or almost daily smokers who had smoked at least five packs of cigarettes per year in their lifetime. Age of smoking initiation, whether they were currently smoking or had already quit, and if so, when they had quit, and on average, how many cigarettes they smoked or had smoked daily were recorded for smokers. The male versus female ratio was about 3:1 in each group. The mean age of patients and controls was $61.4(\mathrm{SD}=10.3)$ and $62.9(\mathrm{SD}=9.8)$ years, respectively. The selective demographic information for all the participants in this study is summarized in Table I.

MMP-7 Genotyping methodology. Genomic DNA was extracted from peripheral blood leukocytes with a QIAamp Blood Mini Kit (Blossom, Taipei, Taiwan), stored long-term at $-80^{\circ} \mathrm{C}$, diluted and aliquoted for genotyping as a working stock at $-20^{\circ} \mathrm{C}$ as we have previously described (43). The MMP-7 genotyping methodology is identical to that published by us in renal cell carcinoma (39). Concisely, the polymerase chain reaction (PCR) cycling conditions were: one cycle at $94^{\circ} \mathrm{C}$ for $5 \mathrm{~min} ; 35$ cycles of $94^{\circ} \mathrm{C}$ for $30 \mathrm{sec} 59^{\circ} \mathrm{C}$ for $30 \mathrm{sec}$ and $72^{\circ} \mathrm{C}$ for $30 \mathrm{sec}$, and a final extension at $72^{\circ} \mathrm{C}$ for $10 \mathrm{~min}$. The genotyping PCR for $M M P-7 \mathrm{~A}-181 \mathrm{G}$ was conducted using the forward 5'-TGGTACCATAATGTCCTGAATG-3' and the reverse 5'-TCGTTATTGGCAGGAAGCACACAATGAATT-3' primer pairs. The obtained $150 \mathrm{bp}$ PCR products were then digested with EcoRI and resulted in two fragments of 120 and $30 \mathrm{bp}$ when the $\mathrm{G}$ allele was present. In the presence of the A allele, the $150 \mathrm{bp}$ fragment remained intact. As for the $M M P-7 \mathrm{C}-153 \mathrm{~T}$, direct sequencing PCR was conducted with the same primers as for $M M P$ 7 A-181G. After amplification, the PCR products were subject to digestion with EcoRI and separation using 3\% agarose gel electrophoresis. All the genotypic processes were repeated by two expert researchers independently and blindly, and their results were $100 \%$ concordant to each other. In addition, the success rate of PCRrestrictive fragment length polymorphism (RFLP) is $100 \%$, and the genotypes of $5 \%$ of the participants in both the control and patient groups were analyzed by PCR direct sequencing (Genomics BioSci $\&$ Tech Co). The concordance between direct sequencing and PCRRFLP methods was $100 \%$.

Statistical analyses. Those participants with complete genotypic and clinical data were subjected to final analysis. The descriptive statistics of patients and controls are presented as the mean and standard deviation (SD) or as percentages. In Table I, the Student's $t$-test was used for the comparison of ages between the case and the control groups. The Pearson's chi-square test or Fisher's exact test (when any cell was less than five) was used to compare the distribution of the genotypes. Associations were evaluated and presented as odds ratios (ORs) with $95 \%$ confidence intervals (CIs). Statistical data was deemed to be significant when the $p$-value was less than 0.05 .

\section{Results}

Comparison of basic characteristics between the bladder cancer patient and the healthy control groups. The frequency distributions of selected basic characteristics including age, 
Table I. Basic characteristics of the 375 patients with bladder cancer and 375 controls investigated in this study.

\begin{tabular}{|c|c|c|c|c|c|c|c|}
\hline \multirow[t]{2}{*}{ Characteristic } & \multicolumn{3}{|c|}{ Controls $(n=375)$} & \multicolumn{3}{|c|}{ Cases $(n=375)$} & \multirow[t]{2}{*}{$p$-Value } \\
\hline & $\mathrm{n}$ & $\%$ & Mean (SD) & $\mathrm{n}$ & $\%$ & Mean (SD) & \\
\hline Age (years) & & & $62.9(9.8)$ & & & $61.4(10.3)$ & $0.7315^{\mathrm{a}}$ \\
\hline Age group (years) & & & & & & & $0.7108^{\mathrm{b}}$ \\
\hline$\leq 55$ & 152 & $40.5 \%$ & & 158 & $42.1 \%$ & & \\
\hline$>55$ & 223 & $59.5 \%$ & & 217 & $57.9 \%$ & & \\
\hline Gender & & & & & & & $0.5525^{\mathrm{b}}$ \\
\hline Male & 287 & $76.5 \%$ & & 279 & $74.4 \%$ & & \\
\hline Female & 88 & $23.5 \%$ & & 96 & $25.6 \%$ & & \\
\hline \multicolumn{8}{|l|}{ Personal habits } \\
\hline Cigarette smoking & 186 & $49.6 \%$ & & 201 & $53.6 \%$ & & $0.3063^{\mathrm{b}}$ \\
\hline Alcohol drinking & 176 & $46.9 \%$ & & 189 & $50.4 \%$ & & $0.3807^{b}$ \\
\hline \multicolumn{8}{|l|}{ Stage } \\
\hline Non-muscle invasive & & & & 235 & $62.7 \%$ & & \\
\hline Muscle-invasive & & & & 140 & $37.3 \%$ & & \\
\hline \multicolumn{8}{|l|}{ Grade } \\
\hline Low & & & & 151 & $40.3 \%$ & & \\
\hline High & & & & 224 & $59.7 \%$ & & \\
\hline
\end{tabular}

SD: Standard deviation; abased on the Student's $t$-test; bbased on Chi-square test.

gender, personal habits, tumor stage and grades for the 375 bladder cancer patients and 375 non-cancer controls are summarized in Table I. Statistically, there was no difference in the distribution of age and gender between the bladder cancer patient and healthy control groups since the frequency matching approach in selecting the recruited non-cancer healthy controls was applied (Table I). Among the investigated individuals, it was found that neither smokers nor alcohol drinkers were of higher percentages in bladder cancer patient group than in the control group (both $p>0.05$ ) (Table I, middle part). The results showed that smoking and alcohol drinking may not be the risk behavioral factors for bladder cancer for Taiwanese. From the clinical viewpoint, the collected bladder cancer patients were more likely to be non-muscle-invasive type $(62.7 \%)$ and later stage $(59.7 \%)$ (Table I).

Association of MMP-7 promoter genotypes and bladder cancer risk among Taiwanese. The genotypic analysis for the MMP-7 A-181G and C-153T among the matched healthy controls and the bladder cancer patients are presented and compared in Table II. The data showed that there are no polymorphic genotypes among the 750 examined subjects at MMP-7 C-153T (Table II, lower panel). The genotypic frequency distributions for $M M P-7$ A-181G were not significantly different between the control and the bladder cancer patient groups ( $p$ for trend=0.5475) (Table II, upper panel). In detail, the AG heterozygosity or GG homozygosity at MMP-7 A-181G seemed not to be associated with any elevated risk of bladder cancer $(p=0.3391$ and 0.6203 , adjusted $\mathrm{OR}=0.80$ and $1.33,95 \% \mathrm{CI}=0.47-1.27$ and $0.46-$ 3.84 , respectively; Table II, upper panel). After Combination of the homozygotes and heterozygotes of the $G$ allele (AG+GG), the analytic results still showed that the $G$ allele at MMP-7 A-181G conferred no risk for bladder cancer $(p=0.4960$, adjusted $\mathrm{OR}=0.84,95 \% \mathrm{CI}=0.54-1.32)$ (Table II). Overall, MMP-7 A-181G seems to play an indirect role in determining personal susceptibility for bladder cancer in Taiwanese population.

Association of MMP-7 promoter allelic frequencies and bladder cancer risk among Taiwanese. The distributions of allelic frequencies for MMP-7 A-181G and C-153T polymorphisms among the bladder cancer patients and the healthy controls are presented in Table III. Supporting the genotyping results in Table II, the results of allelic analysis showed that the $\mathrm{G}$ allele at MMP-7 A-181G was not significantly associated with bladder cancer risk $(p=0.6816$, adjusted $\mathrm{OR}=0.96,95 \% \mathrm{CI}=0.72-1.25$ ) (Table III). In detail, the percentages of minor allele frequencies in the bladder cancer patient and the healthy control groups were $6.5 \%$ and $7.1 \%$, respectively (Table III). Consistent with the findings in Table II, all the investigated subjects were of $\mathrm{C}$ allele at MMP-7 C-153T in Taiwanese population (Table III). Stratification analysis for the MMP-7 A-181G genotypes according to age, gender, smoking and alcohol consumption status was also performed. No significant association was found in any of the stratification analysis among the subgroups (data not shown). 
Table II. Distribution of matrix metalloproteinase-7 A-181G and C-153T genotypic frequencies among the bladder cancer patients and healthy controls.

\begin{tabular}{lcccc}
\hline Genotypes & $\begin{array}{c}\text { Controls, } \mathrm{n}(\%) \\
\mathrm{n}=375\end{array}$ & $\begin{array}{c}\text { Cases, } \mathrm{n}(\%) \\
\mathrm{n}=375\end{array}$ & $\begin{array}{c}\text { Adjusted OR } \\
(95 \% \mathrm{CI})^{\mathrm{a}}\end{array}$ & $p$-Value $^{\mathrm{b}}$ \\
\hline A-181G & & & & \\
AA & $328(87.5)$ & $334(89.1)$ & 1.00 (Reference) & \\
AG & $41(10.9)$ & $33(8.8)$ & $0.80(0.47-1.27)$ & 0.3391 \\
GG & $6(1.6)$ & $8(2.1)$ & $1.33(0.46-3.84)$ & 0.6203 \\
AG+GG & $47(12.5)$ & $41(10.9)$ & $0.84(0.54-1.32)$ & 0.4960 \\
$p_{\text {trend }}$ & & & & 0.5475 \\
-153T & & & & \\
CC & $788(100.0)$ & $956(100.0)$ & 1.00 (Reference) & \\
CT & $0(0.0)$ & $0(0.0)$ & -- & \\
TT & $0(0.0)$ & $0(0.0)$ & -- & \\
$p_{\text {trend }}$ & & & & \\
\hline
\end{tabular}

OR: Odds ratio; CI: confidence interval. aData have been adjusted for confounding factors age, gender, smoking and alcohol consumption behaviors. 'Based on Chi-square test without Yates' correction.

Table III. Allelic frequencies for matrix metalloproteinase-7 A-181G and $C-153 T$ polymorphisms among the bladder cancer patients and healthy controls.

\begin{tabular}{lcccc}
\hline Allelic type & $\begin{array}{c}\text { Controls, } \mathrm{n}(\%) \\
\mathrm{n}=750\end{array}$ & $\begin{array}{c}\text { Cases, } \mathrm{n}(\%) \\
\mathrm{n}=750\end{array}$ & $\begin{array}{c}\text { Adjusted OR } \\
(95 \% \mathrm{CI})^{\mathrm{a}}\end{array}$ & $p$-Value \\
\hline A-181G & & & & \\
Allele A & $697(92.9)$ & $701(93.5)$ & 1.00 (Reference) & \\
Allele G & $53(7.1)$ & $49(6.5)$ & $0.96(0.72-1.25)$ & 0.6816 \\
C-153T & & & & \\
Allele C & $750(100.0)$ & $750(100.0)$ & 1.00 (Reference) \\
Allele T & $0(0.0)$ & $0(0.0)$ & -- & \\
\hline
\end{tabular}

OR: Odds ratio; CI: confidence interval. aData have been adjusted for confounding factors age, gender, smoking and alcohol consumption behaviors. 'Based on Chi-square test without Yates' correction.

\section{Discussion}

From the year of 1979, the widespread use of physical checkup, westernized diet and increased aging of the Taiwanese society, there has been a rising trend in the incidence of urologic cancers, prostate, kidney and bladder cancers, in both Taiwanese male and female populations (44). In the current study, the contribution of $M M P-7$ genotypes to bladder cancer susceptibility in Taiwan was examined. In normal conditions, MMP-7 is commonly expressed in many tissues of the human body, such as in ductal epithelium of exocrine glands in skin, salivary glands, pancreas, glandular epithelium of intestine and reproductive organ, liver, and breast. Since MMP-7 is in charge of degrading ECM macromolecules such as casein, type I-V gelatins, fibronectins and proteoglycans (45), it is hypothesized that hereditary genomic variations may determine personal risk for inflammatory processes, tumor initiation, invasion and metastasis (46).

In the literature, the genotypes of $M M P-7$ have been examined among many types of cancer patients, such as lung, breast, esophageal, gastric, colorectal, gallbladder, oral, cervical cancer, astrocytoma, childhood leukemia and renal cell carcinoma (28-40), but not in bladder cancer (41). However, high tissue and serum levels of MMP-7 are significantly and independently associated with poor prognosis among bladder cancer patients (42).

In the current study, it was found that the $\mathrm{G}$ allele of $M M P-7$ A-181G was not significantly associated with the risk to bladder cancer (Tables II and III). As far as we are aware, the current study is the first to reveal the contribution of $M M P-7$ promoter genotypes to bladder cancer in Taiwan, with a conclusion consistent to the one performed in the Caucasian population (42). Compared with the investigated subjects, our samples are more genetically conserved (all Chinese) and representative ( 375 bladder cancer patients and 375 healthy controls). The presence of the $\mathrm{G}$ allele at MMP-7 A-181G was associated with 2- to 3-fold higher transcriptional activity than that of the A allele, because it reportedly facilitated the binding of nuclear activating proteins in the promoter of MMP-7 (27).

The consistent findings between our study (Chinese) and Polish one about the associations tell us that genetic contribution of MMP-7 A-181G plays a minor role in determining the personal susceptibility to bladder cancer, independently of the race. The environmental factors may play a very important role in bladder cancer. Arseniasis-endemic area in Taiwan, which is associated with well-known black foot disease, contributed to higher incidence of urological cancers, as well as skin cancer and lung cancer (47). In Taiwan, a significant dose-dependent association between arsenic exposure and intake (drinking of arsenic-polluted water) and bladder cancer has been reported in the epidemiological studies focused on populations exposed to high levels of inorganic arsenic $(48,49)$. In addition, the arsenic exposure and urinary profiles of the patients were identified and established as potential biomarkers to predict mortality (50). Although the arsenic-polluted water drinking behaviors in Taiwan were prevented via the widespread tap water supply, we are still exposed in arsenic contamination. The major limitation of the study was the inability to precisely measure the individual's arsenic exposure status such as the water consumed by the patients over their entire lifetime, which made it challenging to accurately estimate the contribution of arsenic exposure to the risk of bladder cancer. In addition, there were no known measurement data on arsenic levels in their blood or urine since this item is not in the list of common examinations.

In conclusion, this study examined the genotypic patterns of MMP-7 A-181G and C-153T among Taiwanese. Neither MMP-7 A-181G nor C-153T contributed to susceptibility of Taiwanese to bladder cancer. Some other markers, other 
MMPs, may be more significant than $M M P-7$ as early detective biomarkers for bladder cancer prediction in Taiwan, and further investigations of the genetic and environmental factors (such as arsenic exposure status) are needed.

\section{Conflicts of Interest}

The Authors declare no interest conflict with any person or company.

\section{Acknowledgements}

The Authors appreciate the Tissue-bank of China Medical University Hospital for their excellent technical assistance. The technical assistance from Huai-Mei Hsu, Hsin-Ting Li and ChiehLun Hsiao is highly appreciated by the Authors. This study was supported mainly by the Taichung Armed Forces General Hospital to Dr. Liao (107A18) and partially by research grant from Taiwan Ministry of Health and Welfare Clinical Trial and Research Center of Excellence (MOHW107-TDU-B-212-123004).

\section{References}

1 Ferlay J, Soerjomataram I, Ervik M, Dikshit R, Eser S, Mathers C, Rebelo M, Parkin DM, Forman D and Bray F: GLOBOCAN 2012 v1.2, Cancer Incidence and Mortality Worldwide: IARC Cancer Base No. 11; 2014. Available from: http://globocan.iarc.fr

2 Torre LA, Bray F, Siegel RL, Ferlay J, Lortet-Tieulent J and Jemal A: Global cancer statistics, 2012. CA Cancer J Clin 65: 87-108, 2015.

3 Chang WS, Tsai CW, Ji HX, Wu HC, Chang YT, Lien CS, Liao WL, Shen WC, Tsai $\mathrm{CH}$ and Bau DT: Associations of cyclooxygenase 2 polymorphic genotypes with bladder cancer risk in Taiwan. Anticancer Res 33: 5401-5405, 2013.

4 Chang WS, Liao CH, Tsai CW, Hu PS, Wu HC, Hsu SW, Hsiao $\mathrm{CL}$, Hsu CH, Hung YW and Bau DT: Association of Enhancer of Zeste 2 (EZH2) genotypes with bladder cancer risk in Taiwan. Anticancer Res 36: 4509-4514, 2016.

5 Cohen SM, Shirai T and Steineck G: Epidemiology and etiology of premalignant and malignant urothelial changes. Scand J Urol Nephrol Suppl (205): 105-115, 2000.

6 Steineck G, Wiholm BE and Gerhardsson de Verdier M: Acetaminophen, some other drugs, some diseases and the risk of transitional cell carcinoma. A population-based case-control study. Acta Oncol 34: 741-748, 1995.

7 Chang $\mathrm{CH}$, Chiu CF, Wang HC, Wu HC, Tsai RY, Tsai CW, Wang $\mathrm{RF}$, Wang $\mathrm{CH}$, Tsou YA and Bau DT: Significant association of ERCC6 single nucleotide polymorphisms with bladder cancer susceptibility in Taiwan. Anticancer Res 29: 5121-5124, 2009.

8 Chang $\mathrm{CH}$, Wang RF, Tsai RY, Wu HC, Wang CH, Tsai CW, Chang CL, Tsou YA, Liu CS and Bau DT: Significant association of XPD codon 312 single nucleotide polymorphism with bladder cancer susceptibility in Taiwan. Anticancer Res 29: 3903-3907, 2009.

9 Chang $\mathrm{CH}$, Chang CL, Tsai CW, Wu HC, Chiu CF, Wang RF, Liu CS, Lin CC and Bau DT: Significant association of an XRCC4 single nucleotide polymorphism with bladder cancer susceptibility in Taiwan. Anticancer Res 29: 1777-1782, 2009.
10 Lekstan A, Lampe P, Lewin-Kowalik J, Olakowski M, Jablonska B, Labuzek K, Jedrzejowska-Szypulka H, Olakowska E, Gorka D, Filip I and Dranka-Bojarowska D: Concentrations and activities of metalloproteinases 2 and 9 and their inhibitors (TIMPS) in chronic pancreatitis and pancreatic adenocarcinoma. J Physiol Pharmacol 63: 589-599, 2012.

11 Sternlicht MD and Werb Z: How matrix metalloproteinases regulate cell behavior. Annu Rev Cell Dev Biol 17: 463-516, 2001.

12 Monteagudo C, Merino MJ, San-Juan J, Liotta LA and StetlerStevenson WG: Immunohistochemical distribution of type IV collagenase in normal, benign, and malignant breast tissue. Am J Pathol 136: 585-592, 1990.

13 Szarvas T, Jager T, Becker M, Tschirdewahn S, Niedworok C, Kovalszky I, Rubben H, Ergun S and vom Dorp F: Validation of circulating MMP-7 level as an independent prognostic marker of poor survival in urinary bladder cancer. Pathol Oncol Res 17: 325-332, 2011.

14 Bond M, Fabunmi RP, Baker AH and Newby AC: Synergistic upregulation of metalloproteinase- 9 by growth factors and inflammatory cytokines: an absolute requirement for transcription factor NF-kappa B. FEBS Lett 435: 29-34, 1998.

15 Groblewska M, Mroczko B, Gryko M, Pryczynicz A, GuzinskaUstymowicz K, Kedra B, Kemona A and Szmitkowski M: Serum levels and tissue expression of matrix metalloproteinase 2 (MMP-2) and tissue inhibitor of metalloproteinases 2 (TIMP-2) in colorectal cancer patients. Tumour Biol 35: 3793-3802, 2014.

16 Saarialho-Kere UK, Crouch EC and Parks WC: Matrix metalloproteinase matrilysin is constitutively expressed in adult human exocrine epithelium. J Invest Dermatol 105: 190-196, 1995.

17 Tsai CW, Chang WS, Gong CL, Shih LC, Chen LY, Lin EY, Li HT, Yen ST, Wu CN and Bau DT: Contribution of Matrix Metallopeptidase-1 genotypes, smoking, alcohol drinking and areca chewing to nasopharyngeal carcinoma susceptibility. Anticancer Res 36: 3335-3340, 2016.

18 Sun KT, Tsai CW, Chang WS, Shih LC, Chen LY, Tsai MH, Ji HX, Hsiao CL, Liu YC, Li CY and Bau DT: The contribution of Matrix Metalloproteinase-1 genotype to oral cancer susceptibility in Taiwan. In Vivo 30: 439-444, 2016.

19 Ye S: Polymorphism in matrix metalloproteinase gene promoters: implication in regulation of gene expression and susceptibility of various diseases. Matrix Biol 19: 623-629, 2000.

20 Price SJ, Greaves DR and Watkins H: Identification of novel, functional genetic variants in the human matrix metalloproteinase2 gene: role of $\mathrm{Sp} 1$ in allele-specific transcriptional regulation. $\mathbf{J}$ Biol Chem 276: 7549-7558, 2001.

21 Yu C, Zhou Y, Miao X, Xiong P, Tan W and Lin D: Functional haplotypes in the promoter of matrix metalloproteinase-2 predict risk of the occurrence and metastasis of esophageal cancer. Cancer Res 64: 7622-7628, 2004.

22 Elander N, Soderkvist $\mathrm{P}$ and Fransen K: Matrix metalloproteinase (MMP) -1, -2, -3 and -9 promoter polymorphisms in colorectal cancer. Anticancer Res 26: 791-795, 2006.

23 Shen TC, Hsia TC, Chao CY, Chen WC, Chen CY, Chen WC, Lin YT, Hsiao CL, Chang WS, Tsai CW and Bau DT: The contribution of MMP-8 promoter polymorphisms in lung cancer. Anticancer Res 37: 3563-3567, 2017.

24 Hung YW, Tsai CW, Wu CN, Shih LC, Chen YY, Liu YF, Hung HS, Shen MY, Chang WS and Bau DT: The contribution of Matrix Metalloproteinase-8 promoter polymorphism to oral cancer susceptibility. In Vivo 31: 585-590, 2017. 
25 Shen TC, Chang WS, Tsai CW, Chao CY, Lin YT, Hsiao CL, Hsu CL, Chen WC, Hsia TC and Bau DT: The contribution of Matrix Metalloproteinase-1 promoter genotypes in Taiwan lung cancer risk. Anticancer Res 38: 253-257, 2018.

$26 \mathrm{Hu}$ PS, Chang WS, Chou AK, Hsia NY, Hung YW, Lin CW, Wu $\mathrm{CW}$, Huang CY, Wu MF, Liao CH, Tsai CW, Bau DT and Gong CL: The association of MMP-8 genotypes with pterygium. In Vivo 32: 41-46, 2018.

27 Jormsjo S, Whatling C, Walter DH, Zeiher AM, Hamsten A and Eriksson P: Allele-specific regulation of matrix metalloproteinase-7 promoter activity is associated with coronary artery luminal dimensions among hypercholesterolemic patients. Arterioscler Thromb Vasc Biol 21: 1834-1839, 2001.

28 Lu Z, Wang Y, Zhang Q, Zhang X, Wang S, Xie H, Li Y, Jiao B and Zhang J: Association between the functional polymorphism in the matrix metalloproteinase-7 promoter and susceptibility to adult astrocytoma. Brain Res 1118: 6-12, 2006.

29 Zhang J, Jin X, Fang S, Wang R, Li Y, Wang N, Guo W, Wang Y, Wen D, Wei L, Dong $Z$ and Kuang G: The functional polymorphism in the matrix metalloproteinase-7 promoter increases susceptibility to esophageal squamous cell carcinoma, gastric cardiac adenocarcinoma and non-small cell lung carcinoma. Carcinogenesis 26: 1748-1753, 2005.

30 Chou AK, Hsiao CL, Shih TC, Wang HC, Tsai CW, Chang WS, Liu LC, Way TD, Chung JG and Bau DT: The contribution of Matrix Metalloproteinase-7 promoter Genotypes in breast cancer in Taiwan. Anticancer Res 37: 4973-4977, 2017.

31 Malik MA, Sharma KL, Zargar SA and Mittal B: Association of matrix metalloproteinase-7 $(-181 \mathrm{~A}>\mathrm{G})$ polymorphism with risk of esophageal squamous cell carcinoma in Kashmir Valley. Saudi J Gastroenterol 17: 301-306, 2011.

32 Fang WL, Liang WB, Gao LB, Zhou B, Xiao FL and Zhang L: Genetic polymorphisms in Matrix Metalloproteinases -1 and -7 and susceptibility to gastric cancer: an association study and metaanalysis. Iran J Allergy Asthma Immunol 12: 203-210, 2013.

33 Moreno-Ortiz JM, Gutierrez-Angulo M, Partida-Perez M, PeregrinaSandoval J, Ramirez-Ramirez R, Muniz-Mendoza R, SuarezVillanueva S, Centeno-Flores M, Maciel-Gutierrez V, CabralesVazquez JE and Ayala-Madrigal ML: Association of MMP7-181A/G and MMP13-77A/G polymorphisms with colorectal cancer in a Mexican population. Genet Mol Res 13: 3537-3544, 2014.

34 Sharma KL, Misra S, Kumar A and Mittal B: Higher risk of matrix metalloproteinase (MMP-2, 7, 9) and tissue inhibitor of metalloproteinase (TIMP-2) genetic variants to gallbladder cancer. Liver Int 32: 1278-1286, 2012.

35 Xie B, Zhang Z, Wang H, Chen Z, Wang Y, Liang H, Yang G, Yang $\mathrm{X}$ and Zhang $\mathrm{H}$ : Genetic polymorphisms in MMP 2, 3, 7, and 9 genes and the susceptibility and clinical outcome of cervical cancer in a Chinese Han population. Tumour Biol 37: 4883-4888, 2016.

36 Lievre A, Milet J, Carayol J, Le Corre D, Milan C, Pariente A, Nalet B, Lafon J, Faivre J, Bonithon-Kopp C, Olschwang S, Bonaiti-Pellie $\mathrm{C}$ and Laurent-Puig P: Genetic polymorphisms of MMP1, MMP3 and MMP7 gene promoter and risk of colorectal adenoma. BMC Cancer 6: 270, 2006.

37 Woo M, Park K, Nam J and Kim JC: Clinical implications of matrix metalloproteinase-1, $-3,-7,-9,-12$, and plasminogen activator inhibitor-1 gene polymorphisms in colorectal cancer. $\mathbf{J}$ Gastroenterol Hepatol 22: 1064-1070, 2007.

38 Pei JS, Chou AK, Hsu PC, Tsai CW, Chang WS, Wu MF, Wu $\mathrm{MH}$, Hsia TC, Cheng SP and Bau DT: Contribution of Matrix
Metalloproteinase-7 genotypes to the risk of non-solid tumor, childhood leukemia. Anticancer Res 37: 6679-6684, 2017.

39 Liao CH, Chang WS, Hu PS, Wu HC, Hsu SW, Liu YF, Liu SP, Hung HS, Bau DT and Tsai CW: The contribution of MMP-7 promoter polymorphisms in renal cell carcinoma. In Vivo 31: 631-635, 2017.

40 Vairaktaris E, Serefoglou Z, Yapijakis C, Vylliotis A, Nkenke E, Derka S, Vassiliou S, Avgoustidis D, Neukam FW and Patsouris E: High gene expression of matrix metalloproteinase-7 is associated with early stages of oral cancer. Anticancer Res 27: 2493-2498, 2007.

41 Wieczorek E, Reszka E, Wasowicz W, Grzegorczyk A, Konecki T, Sosnowski M and Jablonowski Z: MMP7 and MMP8 genetic polymorphisms in bladder cancer patients. Cent European J Urol 66: 405-410, 2014.

42 Szarvas T, Becker M, vom Dorp F, Gethmann C, Totsch M, Bankfalvi A, Schmid KW, Romics I, Rubben H and Ergun S: Matrix metalloproteinase-7 as a marker of metastasis and predictor of poor survival in bladder cancer. Cancer Sci 101: 1300-1308, 2010.

43 Yueh TC, Chou AK, Gong CL, Fu CK, Pei JS, Wu MH, Tsai CW, Chang WS, Hsiao CL, Yen ST, Li HT and Bau DT: The contribution of excision repair cross-complementing group 1 genotypes to colorectal cancer susceptibility in Taiwan. Anticancer Res 37: 2307-2313, 2017.

44 Hung CF, Yang CK and Ou YC: Urologic cancer in Taiwan. Jpn J Clin Oncol 46: 605-609, 2016.

45 Yokoyama Y, Grunebach F, Schmidt SM, Heine A, Hantschel M, Stevanovic S, Rammensee HG and Brossart P: Matrilysin (MMP7) is a novel broadly expressed tumor antigen recognized by antigen-specific T cells. Clin Cancer Res 14: 5503-5511, 2008.

46 Edman K, Furber M, Hemsley P, Johansson C, Pairaudeau G, Petersen J, Stocks M, Tervo A, Ward A, Wells E and Wissler L: The discovery of MMP7 inhibitors exploiting a novel selectivity trigger. ChemMedChem 6: 769-773, 2011.

47 Chen CJ, Chuang YC, Lin TM and Wu HY: Malignant neoplasms among residents of a blackfoot disease-endemic area in Taiwan: high-arsenic artesian well water and cancers. Cancer Res 45: 5895-5899, 1985.

48 Chiou HY, Chiou ST, Hsu YH, Chou YL, Tseng CH, Wei ML and Chen $\mathrm{CJ}$ : Incidence of transitional cell carcinoma and arsenic in drinking water: a follow-up study of 8,102 residents in an arseniasis-endemic area in northeastern Taiwan. Am J Epidemiol 153: 411-418, 2001.

49 Huang YK, Huang YL, Hsueh YM, Yang MH, Wu MM, Chen SY, Hsu LI and Chen CJ: Arsenic exposure, urinary arsenic speciation, and the incidence of urothelial carcinoma: a twelveyear follow-up study. Cancer Causes Control 19: 829-839, 2008.

50 Chung CJ, Huang YL, Huang YK, Wu MM, Chen SY, Hsueh YM and Chen CJ: Urinary arsenic profiles and the risks of cancer mortality: a population-based 20-year follow-up study in arseniasis-endemic areas in Taiwan. Environ Res 122: 25-30, 2013.

Received April 20, 2018

Revised May 29, 2018

Accepted May , 2018 